\title{
Effect of plastic soil on a retaining wall subjected to surcharge loading
}

\author{
Khawla Al-Juari ${ }^{1, a}$, Suhail Khattab and Mohamed Al-Shamam \\ ${ }^{1}$ University of Mosul, Civil Engineering Department, Iraq
}

\begin{abstract}
The seasonal variation and climatic changes play a significant role that affects the stresses exerted on a retaining wall, and the state of stresses in the soil mass behind the wall especially for highly expansive soil. These stresses resulted in the wall moving either away or towards the soil. In this study, a laboratory physical model of the retaining wall formed of a box having $(950 \times 900 \times 600) \mathrm{mm}$ dimensions with one side representing the wall being developed. After the soil being laid out in the box in specified layers, specified conditions of saturation and normal stresses were applied. The wall is allowed to move horizontally in several distances $(0.1,0.2,0.3,0.6,0.8,1.0,2.0$, 3.0 and 4.0$) \mathrm{mm}$, and the stresses being measured, then the vertical loading was released. The main measured variables during the tests are; the active and passive earth pressures, vertical movement of the soil, total suction and time. Results showed that the lateral earth pressure along the depth of the wall largely decreased when wall moved away from the soil. Total suction was slightly affected during wall's movement. At unloading stage, the lateral earth pressure decreased at the upper half of wall height, but increased at the other wall part. Total suction was increased at all depths during this stage.
\end{abstract}

\section{Introduction}

Retaining walls mainly used as lateral support to soil and rock. Cantilever retaining wall is one of the common types of retaining structures. Typical cantilevered walls are T-shaped, L-shaped, or reverse Lshaped. The pressures exerted on these structures can be divided into three categories: at rest, active and passive earth pressures. The direction of wall's movement is the important factor that limits the type of the pressure exerted on retaining structures. Active and passive cases generated when the wall moved away and toward the soil respectively. Whereas at rest case generated when the wall was constructed in a rigid condition and no movement occurred.

Generally, the traditional method in the design of the retaining wall with granular material as a backfill was used, due to simplicity in calculations with no chemical interaction between the soil and the wall and between the soil particles themselves. The effect of lateral swelling pressure exerted on the retaining wall when the clay soil is used as a backfill material was also ignored. Where the lateral swelling pressure is equal to seven times the lateral pressure of the overburden soil without clay [12]. The lateral swelling pressure is more than the vertical swelling pressure and vertical applied stresses $[1,3,8,15,18]$. Consequently, the damage and distress observed in the retaining wall and walls of the building is mainly due to lateral swelling pressure [5, 8].

Several studies were conducted on laboratory physical model of a retaining wall using granular soil as a backfill material $[4,6,9,10,13,17,19,20]$. Whereas, a very limited studies used clayey soil as a backfill material due to the difficulties in dealing with large quantities of the clayey soil. The lateral swelling pressure increased rapidly to a certain depth of the wall and reduced the lateral swelling pressure transmitted to the wall by different approaches $[2,3,7,12,14]$.

This study is, therefore, investigated and considered several factors; the effect of wall's movement toward and far away from the backfill soil on the magnitude of lateral pressure applied on the wall, vertical deformation of the backfill soil and total suction.

\section{Experimental work and testing program}

\subsection{Soil and methodology}

According to the aim of the study, disturbed and undisturbed samples of highly swelling potential are obtained from Al-Majmoua quarter, Mosul city.

The physical properties of the soil used are shown in Table 1.

Table 1. Engineering properties of the soil used

\begin{tabular}{|c|c|c|}
\hline \multicolumn{2}{|l|}{ Property } & Value \\
\hline \multicolumn{2}{|l|}{ Liquid Limit (\%) } & 89 \\
\hline \multicolumn{2}{|l|}{ Plastic Limit (\%) } & 39 \\
\hline \multicolumn{2}{|l|}{ Plasticity index (\%) } & 50 \\
\hline \multicolumn{2}{|l|}{ Shrinkage limit (\%) } & 12 \\
\hline \multicolumn{2}{|l|}{ Linear shrinkage (\%) } & 20.75 \\
\hline \multicolumn{2}{|l|}{ Soil classification } & $\mathrm{CH}$ \\
\hline \multicolumn{2}{|l|}{ Specific gravity } & 2.8 \\
\hline \multicolumn{2}{|l|}{ Total soluble salts (\%) } & 5.6 \\
\hline \multicolumn{2}{|l|}{ Organic matter (\%) } & 1.8 \\
\hline \multicolumn{2}{|l|}{ Sulphate salts } & 0.45 \\
\hline \multicolumn{2}{|l|}{ Gypsum content (\%) } & 5.12 \\
\hline \multicolumn{2}{|l|}{ Sand $(\%)$} & 14 \\
\hline \multicolumn{2}{|l|}{ Silt (\%) } & 34 \\
\hline \multicolumn{2}{|l|}{ Clay $(\%)$} & 52 \\
\hline \multicolumn{2}{|l|}{ Max. dry unit weight } & 14.4 \\
\hline \multicolumn{2}{|c|}{$\left.\begin{array}{l}(\mathrm{KN}) / \mathrm{m} \\
\text { Optimum moisture } \\
\text { content OMC }(\%)\end{array}\right\}$ Standard compaction } & 27.4 \\
\hline \multicolumn{2}{|c|}{$\begin{array}{l}\text { Max. dry unit weight } \\
(\mathrm{kN}) / \mathrm{m}^{3}\end{array}$} & 16.8 \\
\hline \multicolumn{2}{|c|}{$\left.\begin{array}{l}\text { Optimum moisture } \\
\text { content }(\%)\end{array}\right\}$ Modified compaction } & 13.8 \\
\hline
\end{tabular}

\footnotetext{
${ }^{a}$ Corresponding author: khawla_19752012@yahoo.com
} 
The soil classified as $(\mathrm{CH})$ according to the unified soil classification system. The X-ray diffraction analysis of the soil showed that the major clay minerals are montmorillonite, palygorskite, and kaolinite. Whereas, the minor clay minerals are chlorite and illite. The non clay minerals are calcite and quartz.

The experimental set up was designed and built by the authors at The University of Mosul, and it is formed of a steel structure and consists mainly of a box $900 \times 600 \mathrm{~mm}$ in plain and $950 \mathrm{~mm}$ in height. Two sides of the box were made of mild steel plate of $8 \mathrm{~mm}$ thickness, the third side was made of fiberglass plates with $20 \mathrm{~mm}$ thickness to allow observation of the clay deformation during testing. The fourth side of the box was a cantilever movable retaining wall with dimensions $800 \times 450 \mathrm{~mm}$ and thickness $8 \mathrm{~mm}$. At the center line of the retaining wall, four circular openings with diameter $50 \mathrm{~mm}$ were made. The height of these openings from the top of the retaining wall were 100 , 285, 470 and $655 \mathrm{~mm}$ which were used for the installation of the pressure cell transducers. At the edges of the retaining wall, special plastic material was used to prevent leakage and evaporation during the test. The setup was designed to enable lateral swelling pressure, the at rest swelling pressure, active and passive earth pressures measurements. Figure (1) presents the layout of the experimental setup used in this investigation.

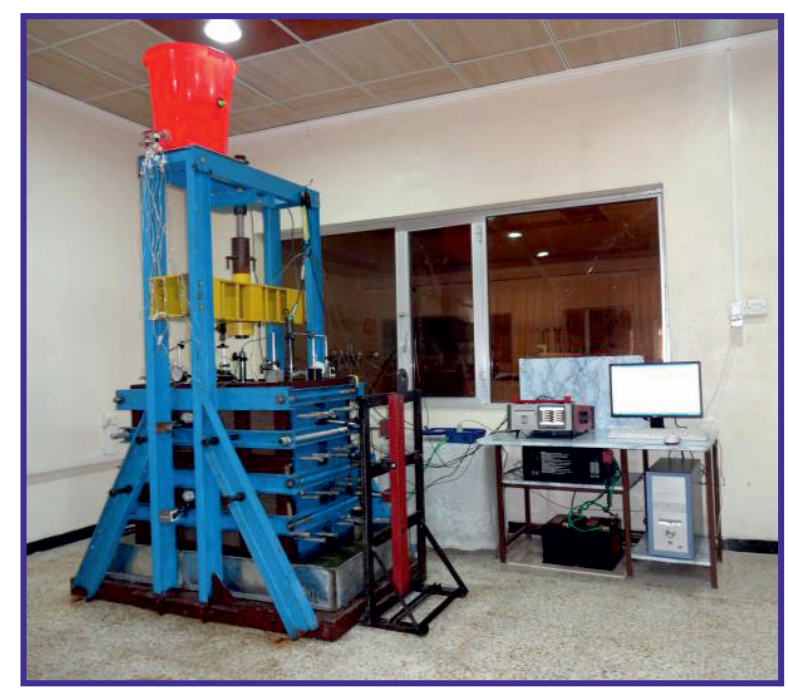

Figure 1. Large scale physical model

\subsection{Soil layout in the box}

At the bottom of the box, a layer of gravel with $100 \mathrm{~mm}$ in thickness, was used to permit a uniformly distribution of water under the bottom surface of the soil. Also, a layer of geogrid was used above the gravel layer to allow the water to pass though it easily.

In order to simulate the plain strain condition, sidewall friction between the soil and box's sides was reduced as low as possible. So, the sides of the box were lubricated with silicon grease. Also, plastic sheets of $70 \mathrm{~mm}$ height were placed on the silicon grease to cover overall height of the box's sides.

The soil was placed in layers and compacted in the box using static compaction method. Compaction pressure applied by electrical hydraulic press until reaching a dry unit weight of $14.4 \mathrm{kN} / \mathrm{m}^{3}$ and optimum moisture content $27.4 \%$. Where the initial degree of saturation of the soil sample was $81.27 \%$. The compaction was achieved in the box in 14 layers. The thickness of each layer was $50 \mathrm{~mm}$ to reach an overall depth of $700 \mathrm{~mm}$. The compaction pressure was kept for two hours to prevent rebound of soil, and insure that the top soil is on the required level. Five holes were bored by a special hand auger with diameter of $20 \mathrm{~mm}$. Three of them were made on the left side of the box at depths of 100, 345 and $590 \mathrm{~mm}$. Also, two holes were made on the back of the box at depths of 100 and 345 $\mathrm{mm}$. These holes were used to install calibrated water probes which have the capacity of $239 \mathrm{kPa}$. The probes were used for measuring the total suction of the soil. Beside that, the probes were utilized to check the variation of the total suction at different depths and different locations on the same soil levels.

When compaction process completed, a rectangular steel plate of dimensions $786 \times 468 \mathrm{~mm}$ was placed at the top of the compacted soil surface, where the center line of the steel plate and soil surface was coincided. Then, all the equipments were installed in appropriate positions. So, three linear variable displacement transducer LVDTs with capacity of $100 \mathrm{~mm}$ were fitted on the longitudinal center line surface. Four pressure cells with capacity of $2 \mathrm{~N} / \mathrm{mm}^{2}$ were installed on the retaining wall. Finally, another three LVDTs with capacity of $25 \mathrm{~mm}$ were installed on a steel mesh which was placed in front of the retaining wall, and their pointer were localized on the pressure cells to measure the wall's movement.. Figure (2) shows a schematic diagram of the model with their instrumentation devices.

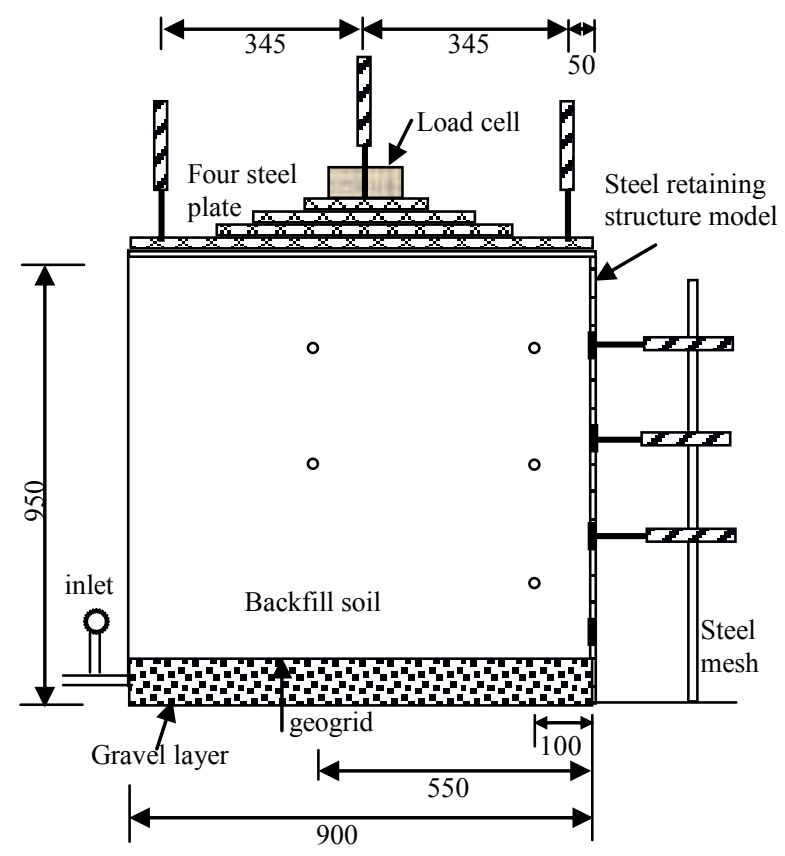

All dimensions in ( $\mathrm{mm})$

$$
\text { Pressure cell LVDT }
$$

Figure 2. Schematic diagram of the model with their instrumentation devices 


\subsection{Saturation and load application}

Expansive soil could exert a lateral pressure on retaining wall, when suction changes within soil due to rainfall and seasonal change of water table. Thus in this study, the soil was saturated from the top and bottom of the box using a water tank which was placed at the top of hydraulic press frame and filled with water as shown in Figure (1), which was used to provide water on all sides of a rectangular plate and consequently, water penetrate to the soil mass by gravity. The water inlet at the bottom of the box was connected to the water source and water can rise by the capillarity.

After saturation stage, the soil was subjected to the vertical load by a mechanical hydraulic jack. Four plates with load cell and their circular disk were arranged, and placed at the surface of the compacted soil, the center line of mechanically hydraulic jack, load cell and jointed plates were coincided with the center line of the top soil surface. More details of results of the saturation and loading stages can be found in [16].

\section{Results and discussion}

\subsection{Wall's movement stage}

The soil sample was subjected to saturation and loading up to $214.3 \mathrm{kPa}$. The wall remained stable without movement, using four steel tides and guides at different depths. Also, the wall was fixed by seven rivets at the bottom of the wall. The wall's movement represented active case of the retaining wall. The wall was moved horizontally away from the soil at distances $0.1,0.2$, $0.3,0.6,0.8,1.0,2.0,3.0$ and $4.0 \mathrm{~mm}$ after the rivets at the bottom of the wall were opened, and the movement was controlled by the guides. The movement of the wall was measured by LVDTs which were localized on each pressure cell and monitored by data logger. At each step of wall's movement the following parameters were studied:

1. Effect of wall's movement on the lateral stresses.

2. Effect of wall's movement on the settlement of the backfill soil.

3. Effect of wall's movement on the total suction of the backfill soil.

\subsubsection{Effect of wall's movement on the lateral stresses}

Figure (3) shows the relationship between lateral pressures and wall's movement. It can be noted, that the lateral stresses decreased with the increase of wall's movement at all depths. These results coincide with findings of $[11,17]$ when moving the retaining wall away from the backfill sandy soil in horizontal and rotation movement about the base of the wall. Rapid decrease in lateral stresses occurred when the wall's movement range between 0.1 to $1.0 \mathrm{~mm}$, where at 1.0 $\mathrm{mm}$ the percent of decrease reached $90,85,75$ and 55 $\%$ at depths $0.1,0.285,0.47$ and $0.655 \mathrm{~m}$, respectively. Then, the decrease will be slow with the increase of wall's movement. It should be noted, the rate of decrease in lateral stresses, at wall's movement more than $1.0 \mathrm{~mm}$ and at depths 0.47 and $0.655 \mathrm{~m}$ are more than that at depths 0.1 and $0.285 \mathrm{~m}$.

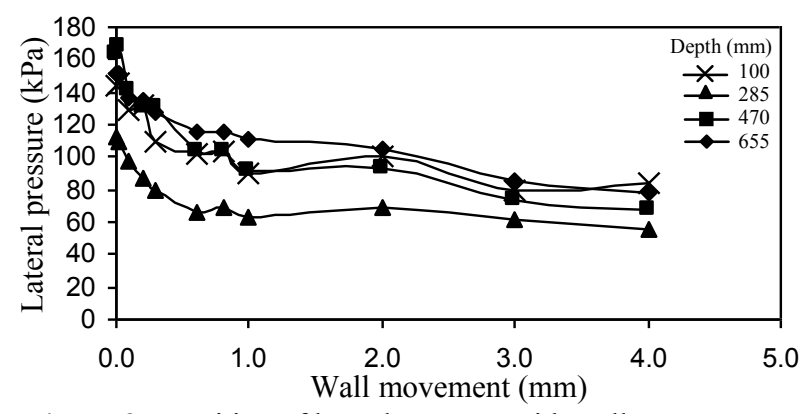

Figure 3. Varaition of lateral pressure with wall movement

To investigate the effect of elapsed time on the behavior of lateral stresses during steps of wall's movement, the wall was left for many hours at each step of wall's movement until the lateral stresses reached an equilibrium state. Figure (4) shows results that illustrate the effect of elapsed time on the distribution of lateral stresses. Generally, the lateral stresses suddenly decreased with high values immediately after wall's movement, then increased within 30 minutes and reached an equilibrium states after hours.

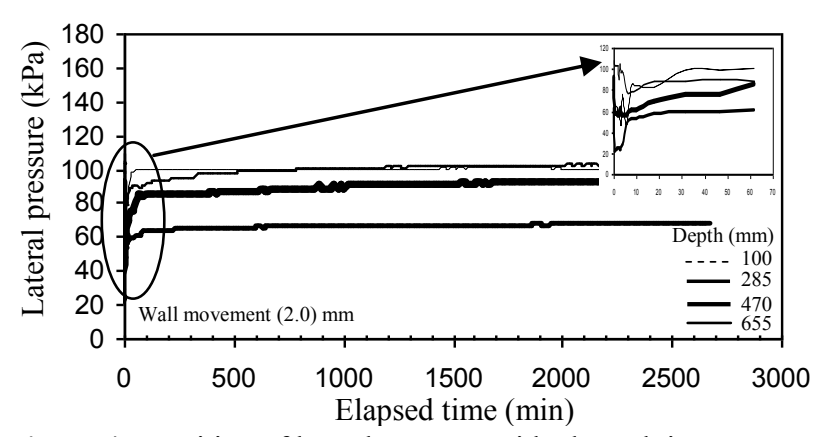

Figure 4. Varaition of lateral pressure with elapsed time

\subsubsection{Effect of wall's movement on the settlement of the backfill soil}

The settlement of the backfill expansive soil was measured, when the wall's movement was at different steps $0.1,0.2,0.3,0.6,0.8,1.0,2.0,3.0$ and $4.0 \mathrm{~mm}$. The settlement was measured using two LVDTs, one of them fixed directly behind the wall, the other was fixed away from the wall. Figure (5) shows the relationship between the settlement of the backfill expansive soil and wall's movement. The settlement increased with the increase of wall's movement. The settlement of soil when the wall was moved $4.0 \mathrm{~mm}$ is equal to 11.04 and 9.15 times the settlement of soil, when the wall was moved $0.1 \mathrm{~mm}$ behind the wall and away from the wall, respectively. The percent of increase in settlement increased from $(1.04,1.43)$ up to $(8.79,13.84) \%$ when the wall was moved from ( 0.1 to 4$) \mathrm{mm}$ at away from and behind the wall, respectively.

It should be noted, the settlement behind the wall was more than that away from the wall at each step of wall's movement. From these results, it can be concluded that the surface of the backfill soil was sloped toward the retaining wall. 


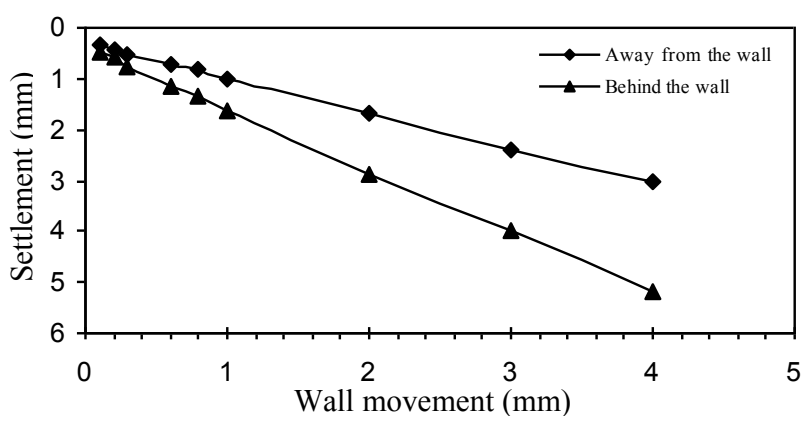

Figure 5. Settlement of the backfill Soil with wall movement

\subsubsection{Effect of wall's movement on the total suction of the backfill soil}

To study the effect of wall's movement on the total suction of the soil, readings of total suction were obtained from water mark monitor during each step of wall's movement with one hour interval.

Figure (6) shows the variation of total suction with wall's movement at different locations and depths. The total suction increased slightly with wall's movement up to a maximum value of $7.0 \mathrm{kPa}$ at the middle side of the soil sample during the test. Also, the total suction increased at the whole depth. The range of increase in total suction when the wall was moved from (0.1 to 1.0$)$ $\mathrm{mm}$ was (0 to 4.0$) \mathrm{kPa}$. Then, when the wall was moved from (1.0 to 4.0$) \mathrm{mm}$ the range of increase of the total suction was (1.0 to 3.0$) \mathrm{kPa}$. This implies that the wall's movement has a very limited effect on the total suction of the soil.

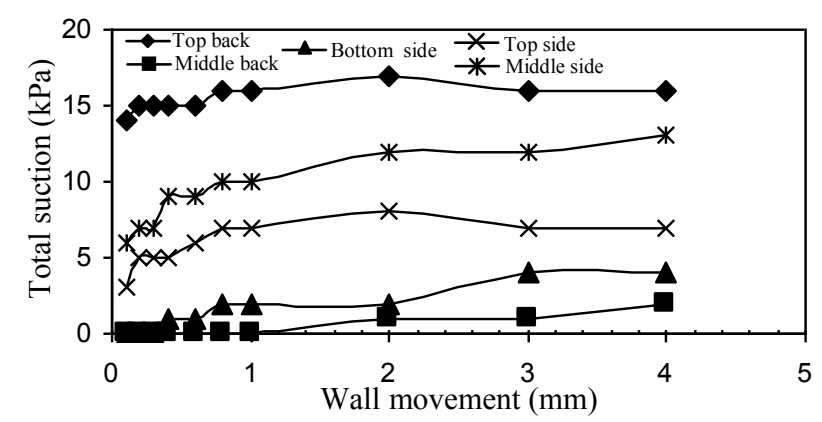

Figure 6. Variation of total suction during wall movement

\subsection{Unloading Stage}

Table (2) shows the unloading steps of the vertical stresses. During this stage, the wall was left to move freely. Where all guides that limit the movement of the wall were removed. At each step of the vertical stresses release, the following parameters were measured by sensors:

1. Effect of unloading on the lateral stresses.

2. Effect of unloading on the vertical stresses with time.

3. Effect of unloading on the settlement of the backfill soil.

4. Effect of unloading on the total suction of the backfill soil.
Table 2. Steps of unloading stage

\begin{tabular}{|c|c|c|}
\hline \multirow{2}{*}{ Steps } & \multicolumn{2}{|c|}{ Vertical stress (kPa) } \\
\cline { 2 - 3 } & From & To \\
\hline 1 & 214.3 & 160.7 \\
\hline 2 & 160.7 & 107.1 \\
\hline 3 & 107.1 & 53.57 \\
\hline 4 & 53.57 & 26.78 \\
\hline 5 & 26.78 & 13.39 \\
\hline 6 & 13.39 & 0 \\
\hline
\end{tabular}

\subsubsection{Effect of unloading on the lateral stresses}

Figure (7) shows the results of lateral stresses at different depths due to the unloading stage. The lateral stresses at the depths 0.1 and $0.285 \mathrm{~m}$ decreased with the decrease of vertical stresses. However, at depths 0.47 and $0.655 \mathrm{~m}$ the lateral stresses increased. This is not identical with the findings of [17]. This behavior is may be attributed to the unloading which caused a decrease in lateral stresses as the soil attempted to move away from the wall and then a decrease in the lateral pressure observed. However, the upper part of the wall moved towards the soil when the soil rebounded, in which this upper part movement of the wall caused a rotation of the bottom part away from the soil. This in turn caused the soil, at the deepest depths of 0.47 and $0.655 \mathrm{~m}$, to be swelled towards the wall. Therefore, an increase of horizontal stresses on the wall and lateral pressure observed.

The decrease in the lateral stresses at depth $0.1 \mathrm{~m}$ was more than that at depth $0.285 \mathrm{~m}$ at all levels of vertical stresses release. Thus, the slope of the curve as shown in Figure (7) at depth $0.1 \mathrm{~m}$ is more than that at depth $0.285 \mathrm{~m}$.

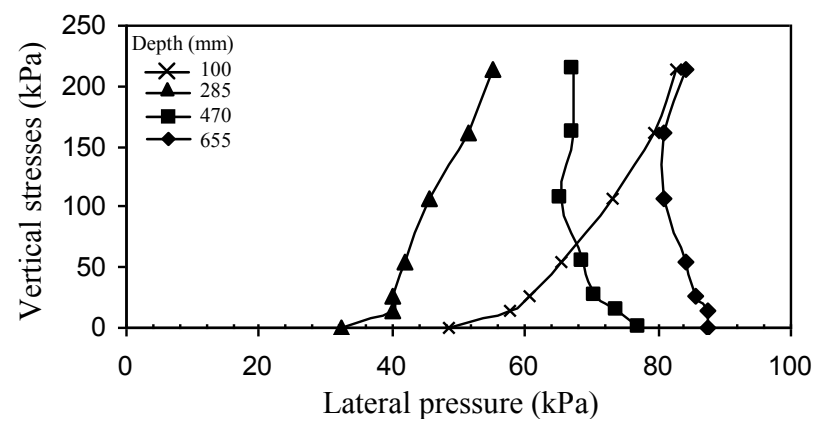

Figure 7. Change in lateral pressure at unloading stage

\subsubsection{Effect of unloading on the vertical stresses with time}

During the unloading stage the vertical stresses was left for many hours, the vertical stresses reduced to values less than the initial values within several minutes, then increased with elapsed time. Figure (8) shows the variation in vertical stresses with elapsed time. It should be noted, that the vertical stresses suddenly decreased 
and reached the minimum value, within the time ranged between 2.5 to $5.8 \mathrm{~min}$ as shown in Table (3). Then, followed by an increase in the vertical stresses with time until reached an equilibrium state. The rate of increase in vertical stresses decreased with the reduction in vertical stresses. Therefore, the time required to obtain the stability of vertical stresses increased with the decrease of vertical stresses, which ranged between 44.25 to $1945.99 \mathrm{~min}$. Table (3) also shows the amount and percent of return in the vertical stresses with time. It should be noted, the percent of return increased with the reduction in the vertical stresses, which reached two times at stress level $13.39 \mathrm{kPa}$. The return in the vertical stresses is related to the ability of highly expansive soil to exert uplift pressure.

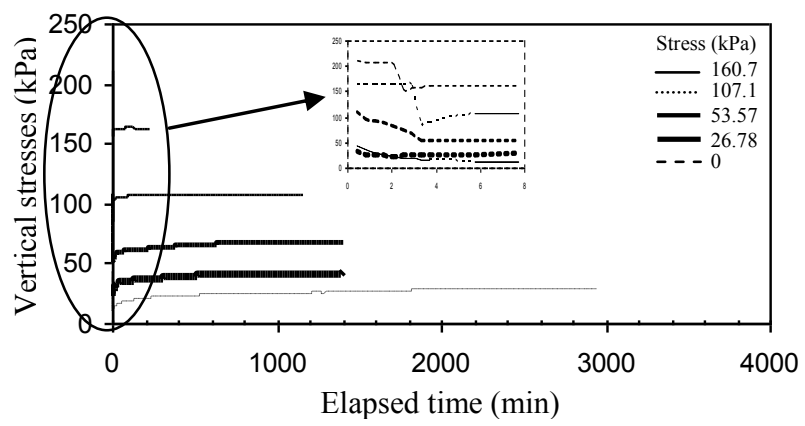

Figure 8. Variation in the vertical stresses with time

Table 3. Variation of the vertical stresses with time

\begin{tabular}{|c|c|c|c|c|c|c|c|}
\hline 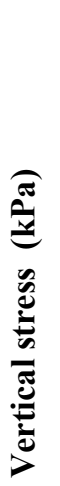 & 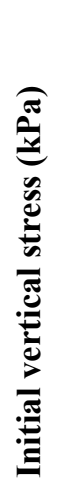 & 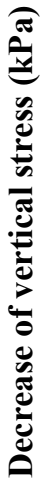 & 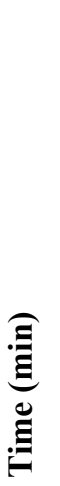 & 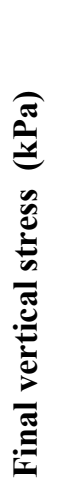 & 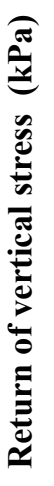 & 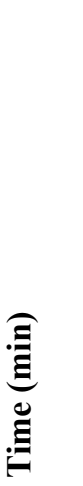 & 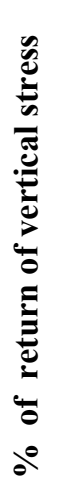 \\
\hline 160 & 156 & 58 & 2.5 & 163 & 7 & 44 & 4.7 \\
\hline 107 & 85 & 78 & 3.3 & 108 & 23 & 838 & 26 \\
\hline 53 & 51 & 57 & 3.3 & 66 & 15 & 598 & 29 \\
\hline 26 & 22 & 44 & 2.1 & 42 & 20 & 1410 & 93 \\
\hline 13 & 9 & 33 & 5.8 & 28 & 19 & 1946 & 199 \\
\hline
\end{tabular}

\subsubsection{Effect of unloading on the settlement of the backfill soil}

In this stage, the applied vertical stresses were released in steps as mentioned previously. So, the backfill soil rebounded. Figure (9) shows the decrease in settlement with the release of applied vertical stresses. It should be noted the rebound curves have the same trend. Table (4) shows the amount and percent of decrease in the settlement of the backfill soil behind the wall, which is slightly more than that away from the wall, that is refer to the uniformity in rebound of expansive soil when the vertical stress was released.

The reduction in the settlement was small up to vertical stress $53.57 \mathrm{kPa}$, then increased especially at stress level 13.39 and $0 \mathrm{kPa}$. The amount and percent of decrease in settlement at stress level $13.39 \mathrm{kPa}$ are more than twice that at stress level $26.78 \mathrm{kPa}$.

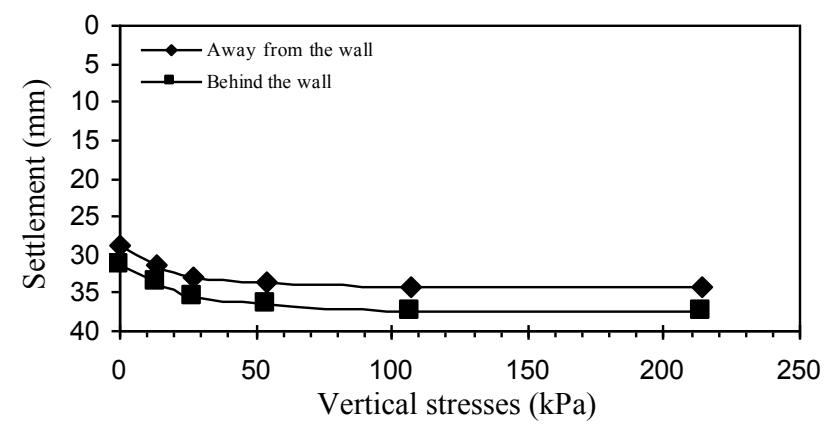

Figure 9. Variation of settlement during unloading

Table 4. Variation of settlement at unloading stage

\begin{tabular}{|c|c|c|c|c|}
\hline 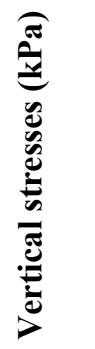 & 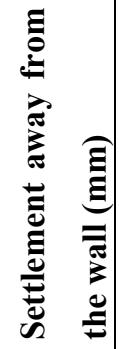 & 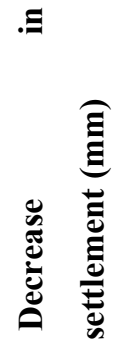 & 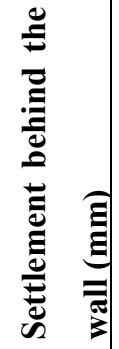 & 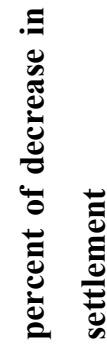 \\
\hline 214.3 & 34.35 & - & 37.5 & - \\
\hline 107.1 & 34.19 & 0.4367 & 37.37 & 0.3467 \\
\hline 53.57 & 33.59 & 2.183 & 36.61 & 2.3733 \\
\hline 26.78 & 32.95 & 4.0466 & 35.66 & 4.9067 \\
\hline 13.39 & 31.25 & 8.9965 & 33.71 & 10.107 \\
\hline 0 & 28.69 & 16.448 & 31.37 & 16.347 \\
\hline
\end{tabular}

\subsubsection{Effect of unloading on the total suction of the backfill soil}

The total suction at all depths and locations increased with the reduction of the vertical stresses as shown in Figure (10). The maximum increase in total suction was $20 \mathrm{kPa}$ occurred at the top side of the box. The curves in Figure (10) at the top side and top back of the box have the same trend because of the difference in the total suction between them was small, which is related to the plastic nature of highly expansive soil, that helped the top layer to increase its height uniformly and permit the air entrance to the soil. Thus, the total suction increased on the same values.

At middle layer, the total suction increased with a rate slightly less than that at the top layer. This is because the top layer was more affected by the reduction of the vertical stresses than the middle and 
bottom layers. The increase in the total suction in the middle back was more than that of the middle side until reaching the same values of $20 \mathrm{kPa}$ when the vertical stresses became $13.39 \mathrm{kPa}$.

At the bottom layer, the total suction increased with a very slow rate compared to the top and middle layers. The increase in the total suction decreased with the decrease of the vertical stresses to reach $1 \mathrm{kPa}$ when the vertical stresses were reduced from 13.39 to $0 \mathrm{kPa}$.

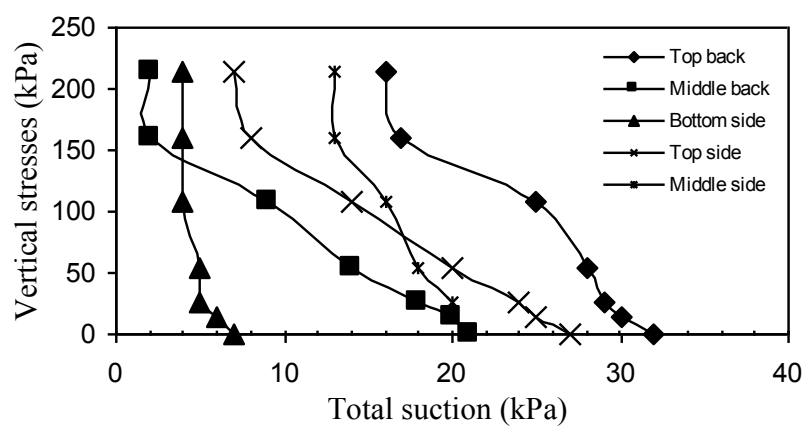

Figure 10. Variation of total suction during unloading stage

\section{Conclusions}

From the study carried out, the following conclusions can be withdrawn;

1- The lateral stresses largely decreased when the retaining wall was moved away from the backfill soil.

2- The settlement of the backfill soil increased with increasing the wall's movement away from the backfill soil. Also, the settlement behind the wall was more than that away from the wall at each step of wall's movement.

3- The effect of the wall's movement on the total suction was marginal.

4- During the unloading stage, the lateral stresses increased at the middle and bottom layers and decreased at the top layer.

5- The same amount of the settlement was obtained behind and away from the wall during the unloading stage.

6- The total suction increased during unloading, and the increase in the total suction at the top layer of soil sample is more than that at the middle and bottom layers.

\section{References}

1- B. Fourie, "Laboratory Evaluation of Lateral Swelling Pressure". J. Geo. E. ASCE. 115, 14811486 (1989).

2- B. Ikizler, M. Aytekin, E. Nas, "Laboratory study of expanded polystyrene (EPS) geofoam used with expansive soils". Geot and Geom. 26, 189-195 (2008).

3- C. Clayton, I. Symons, J. Hiedra-Cobo, "The Pressure of Clay Backfill Against Retaining Structures" Can. Geot. J. 28, 282-297 (1991).

4- C. Huang, W. Luo, "Behavior of Soil Retaining Walls on Deformable Foundations". E. Geol. 105, 1-10(2009).
5- E. Marsh, R. Walsh, "Common Causes of RetainingWall Distress: Case Study". J. Per. Con. Fac.. 10, 35-38 (1996).

6- L. Tagle, F. Villalobos, "Experimental Study of the Lateral Earth Pressure On Retaining Structures In Soils Reinforced With Geogrids". Rev. Ing. Constr. 26, 299-320 (2011).

7- L. Wang, S. Liu, B. Zhou, "Experimental Study on the Inclusion of Soilbags in Retaining Walls Constructed in Expansive Soils". Geot. Geom. J. 43, 89-96 (2015).

8- M. Ozer, R. Ulusay, N. Isik, "Evaluation of Damage to Light Structures Erected on a Fill Material Rich in Expansive Soil". B. E. Geol. Env. 71, 21-36 (2012).

9- M. Pinto, T. Cousens, "Effect Of The Foundation Quality On A Geotextile-Reinforced, Brick-Faced Soil Retaining Wall", Geos. Int. 7, 217-242 (2000).

10- O. Ertugrul, A. Trandafir, "Lateral Earth Pressures on flexible Cantilever Retaining Walls with Deformable Geofoam Inclusions". E. Geo. 158, 23-33(2013).

11- O. Mohamed, Y. Taha, S. Abd El-Aziz, "Experimental Study on the Effect of Lateral Swelling Pressure of Expansive Soil on Retaining Structure". J. E. Sci. 42, 84-92 (2014).

12- O. Mohamed, Y.Taha, S. Abd El-Aziz, "Field Study of the Distribution of Lateral Swelling Pressure of Expansive Soil on Retaining Structure". J. E. Sci. 42, 289-302 (2014).

13- R. Chen, Y. Chiu, " Model Tests Of Geocell Retaining Structures", Geot. Geom. 26, 56-70 (2008).

14- R. Katti, E. Bhangale, K. Moza, "Lateral Pressure in Expansive Soil With and Without a Cohesive Non-Swelling Soil Layer, Application to Earth Pressures on Cross Drainage Structures in Canals and Key Walls in Dams", C. B. Irr. P. 110, 1-303 (1983).

15- R. Thompson, R. Mckeen,. "Heave Prediction Using Soil Suction a Case History". S. S App. Geot. E. P. ASCE. 1-13 (1995).

16- S.A. Khattab, M.K. Al-Shamam, K.A. Al-Juari, "Model Test on Lateral Earth Pressure of highly Expansive soil". Proc. 6th Asia pacific Conf. on Unsat. Guilin, China, 709-716 (2015).

17- T. Dave, S. Dasaka, "Transition of Earth Pressure on Rigid Retaining Walls Subjected to Surcharge Loading". Int. J. Geo. E. 6, 427-435 (2012).

18- Y. Ertekin, "Measurement of Lateral Swell Pressure with Thin Wall Oedometer Technique". MSc. Thesis, Middle East Technical University (1991).

19- Y. Tsukamoto, K. Ishihara, T. Higuchi, H .Aoki, "Influence of Geogrid Reinforcement on Lateral Earth Pressures Against Model Retaining Walls". Geo. Int. 6,195-218 (1999).

20- Z. Mengxi, Z. Huai, "Model Test on Sand Retaining Wall Reinforced with Denti-Strip Inclusion". Sci. Ch. S. E. Tech. Sci.. 51, 2269-2279 (2008). 